\title{
Immediate Percutaneous Coronary Intervention for ST Elevation Myocardial Infarction
}

National Cancer Institute

\section{Source}

National Cancer Institute. Immediate Percutaneous Coronary Intervention for ST

Elevation Myocardial Infarction. NCI Thesaurus. Code C99961.

An immediate percutaneous coronary intervention is necessary for a myocardial

infarction that presents with ST segment elevation. (ACC) 